\title{
Disciplining the Notion of "Labour Rights as Human Rights"
}

\author{
Cedric Dawkins, Loyola University Chicago, USA \\ Christina Dawkins, A4Abolitionist, USA
}

\begin{abstract}
Beleaguered labour movement advocates are turning to the "labour rights as human rights" framing to address labour issues that have traditionally been tackled by labour unions. Human rights language is indispensable in making the normative case that labour is not a commodity, but an unstructured adoption of the human rights frame poses the spectre of a diminished role for collective labour rights and an overburdened human rights regime. Under the principle of subsidiarity, the notion of human rights substitutes for core labour rights (i.e., freedom of association) where they are absent and reinforces them when they are present. Beyond simply suggesting that both regimes are used to protect labour rights, we propose using the principle of subsidiarity to structure and reinforce the interdependence of human and labour rights.
\end{abstract}

\section{KEYWORDS}

Labour rights; human rights; core labour standards

The challenges posed by global corporations have outpaced the regulatory capacity of countries, individually and collectively, and brought increased attention to the impacts of corporate practice on human and labour rights (Matten and Crane, 2005; Wettstein, 2012a). At the same time, amid labour union struggles and calls for revitalisation, there is heightened attention to pursuing labour rights through the human rights regime, an approach loosely termed labour rights as human rights (Compa, 2000; Atleson, 2004). (The two concepts are defined and discussed in detail in the next section.) While human rights are primarily oriented toward designating the appropriate role of the state in the lives of its citizens and, arguably, achieving outcomes such as better working opportunities and conditions, labour rights generally emphasise limiting the power of private actors in the market, are more collectively oriented, and preference workers' agency and collective negotiations (Youngdahl, 2009; Kolben, 2010). Among advocates of labour movement revitalisation, the move to human rights framing is as much a pragmatic turn - in response to declining political and intellectual support for labour unions and the potential leverage offered by human rights language and methods - as a principled one (Hilgert, 2009; Fenwick and Novitz, 2010). Proponents claim that this framing helps observers to view labour rights as a human rights mission, rather than as an economic contest between labour and capital (Gross and Compa, 2009).

Indeed, no group of rightsholders is more closely impacted by corporate human rights practices than workers. During the 1990s, groups of trade unionists, human rights advocates and scholars were discussing ways to address the erosion of workers' organising and bargaining rights

Global Labour Journal, 2022, 13(1), Page 2 
in the United States (US), and determined to reframe labour rights on a foundation of human rights principles (see Compa, 2008). Framing influences how individuals perceive events by highlighting certain features over others and is a useful means of advancing social goals (Tversky and Kahneman, 1990; Benford and Snow, 2000). When, in 1995, Hillary Clinton asserted that "women's rights are human rights"1 and should "no longer [be discussed] as separate from human rights", she confronted the notion that being separate implied less importance and standing (Tyler, 1995; Clinton, 1996). Her speech in Beijing propelled the framing of various rights as "human rights" into the contemporary rights lexicon (Chozick, 2015), and for better or worse, it has become a "moral lingua franca in international affairs" (Moyn, 2018: 168).

Subsequently, the labour rights as human rights strategy has taken root not only because of its normative appeal, but also because of its connection to the human rights regime, including international law and its shaming methodology (e.g. Esthund, 2002; Fudge, 2007b). Proponents see promise in the emotive force of human rights to garner support beyond the reach of various labour rights complaints, such as low wages or poor working conditions, which can struggle to gain traction. For example, recent Human Rights Watch (2010) reports frame poor labour conditions as affronts to human rights. However, some labour advocates and scholars question framing labour rights as human rights and call for a careful assessment of its costs and benefits (e.g. Brody, 2001; Alston, 2005). Because labour movement decline is not solely attributable to job displacement and technological and economic causes, but also to moral and ideological factors that challenge the role and normative standing of collective labour rights in society and in the lives of workers (Lichtenstein, 2003; Fletcher and Gapasin, 2008), framing labour rights as human rights can unwittingly weaken fundamental workplace democracy and economic justice. Critically, there is no normative distinction to be drawn between human rights and labour rights. Both regimes are motivated by a commitment to justice and protecting the oppressed, and both employ rights principles and language in their advocacy (Kolben, 2010). Moreover, if human rights impose correlative moral duties on other actors who might impede or facilitate them (Nussbaum, 2002), then the relationship between human and labour rights has broad implications for if and how labour rights are realised. Hence, the goal of this paper is to carefully align the traditional labour rights and "labour rights as human rights" approaches.

Subsidiarity, derived from the Latin root subsidere, to support, is a regulative principle that disciplines the way various persons and institutions interact with one another in pursuit of their common objectives. In the late 1800s, Pope Leo XIII introduced the principle of subsidiarity in his Rerum Novarum, ${ }^{2}$

Whenever the general interest or any particular class suffers, or is threatened with harm, which can in no other way be met or prevented, the public authority must step in to deal with it; but ... the law must not undertake more, nor proceed further, than is required for the remedy of the evil or the removal of the mischief (Leo XIII, 1891).

In other words, subsidiarity requires the higher authority to intervene and assist the lower authority, but must not intrude to the point of absorbing or preventing the lower authority from

1 The phrase is said to have originated with feminist movements in South America circa 1920. See Marino (2019).

2 The principle of subsidiarity has ancient roots and versions can be traced back thousands of years. For a thorough treatment see Carozza (2003). 
accomplishing what it can on its own. We will argue that subsidiarity is an appropriate structural principle with which to align and deploy the complementary, if different, notions of human rights and labour rights at higher and lower levels of activity, while promoting and protecting them both. More specifically, we maintain that the question is not whether to use either human rights language and framing or the traditional labour rights regime, but when to use one and when to use the other, and to employ the principle of subsidiarity to enhance their interdependence. In what follows, the article describes human and labour rights in some detail, as well as the relationship between the human and labour rights regimes. Thereafter, it details the principle of subsidiarity and how it can be employed to discipline the relationship between human and labour rights.

\section{Human Rights and Labour Rights}

The unique dynamic between the human and labour rights regimes emerges partly from their interdependence; even as people are born free and equal in dignity and rights, the capacity to experience that freedom and dignity depends heavily on the ability to earn a living. Human rights are basic moral entitlements that accrue equally to people solely by virtue of their humanity and regardless of the prevailing legal or social structures or their spatial location (Nickel, 1987). The core of the human rights regime is the International Bill of Human Rights (IBHR), which consists of the Universal Declaration of Human Rights (UDHR), the International Covenant on Economic, Social and Cultural Rights (ICESCR), and the International Covenant on Civil and Political Rights (ICCPR). Labour rights, on the other hand, can be viewed as a subset of moral entitlements that relate to the context of employment (Dawkins, 2012). The relationship between human rights and labour rights is of conceptual and practical importance.

In presenting the human rights obligations of corporations, Arnold (2010) categorises human rights as either basic or aspirational. Basic rights, such as physical integrity and freedom of conscience, are morally inalienable "claim rights" that have maximal moral force and obligate others. Aspirational rights, such as quality education or access to a decent wage, are reasonably derivative of basic rights that "foster a flourishing and fully realized human existence, but are aspirational in the sense that they are difficult, or impossible, to secure universally" (Arnold, 2010: 386). Importantly, a decent wage assumes employment and differs from a right to subsistence - the minimum food and shelter required to support life - which can also be remedied outside of employment. One must also consider the issue of the obligation-bearer, without which the extent of obligation cannot be determined nor a right exercised. For example, if rights are primarily political and legal, this involves the nation-state as primary duty bearer but if rights are moral claims, they imply a broader range of correlative duties for other involved actors (e.g., Wettstein, 2012b; Wood, 2012). Hence, the manner in which rights, human or labour, are construed impacts whether and how those rights are actually realised. Building on the distinction between basic and aspirational rights, human rights provide the strongest foundation for establishing obligations when they are limited in scope, widely supported among rightsholders, and entail only those minimal conditions that allow the powerless to help themselves (Ignatieff, 2003; Arnold, 2010).

To extend this reasoning, if human rights are the most basic and essential, appeals to protecting labour rights as human rights are likely to be strongest when limited to the most basic and indispensable labour rights. Notwithstanding this, labour advocates differ regarding the extent to which labour rights advocacy should draw from human rights. The "traditional labour rights" approach, which is centred on labour unions and collective action, draws narrowly from 
the human rights regime (Kolben, 2010; Walchuk, 2011), and generally aligns with the notion that economic rights are aspirational. The "labour rights as human rights" approach is centred on human rights, emphasises corporate campaigns aimed at public shaming, leans on international soft law, and may or may not include labour unions. The belief is that, "[t]he expertise and knowledge attributable to human rights actors [gives] their critique of workers' rights violations in the U.S. a high measure of authoritativeness compared with trade unionists making the same claims" (Compa, 2008: 99). This approach helps labour rights attain a measure of human rights standing (Gross, 2002; Fudge, 2007a) and benefits from the involvement of civil society organisations, such as the Fair Wear Foundation ${ }^{3}$ and the Clean Clothes Campaign. ${ }^{4}$

By way of illustration, consider two responses to the same issue, a decent wage, that typify the traditional labour rights and labour rights as human rights approaches, respectively.

1. The traditional labour rights approach. When Fruit of the Loom (FOTL), parent company of Russell Athletic, closed a factory in Honduras and laid off 1200 workers who had formed a labour union to improve wage rates, union leaders coordinated a campaign with United Students Against Sweatshops (USAS) ${ }^{5}$ that included a speaking tour of American universities. The objective of the worker-led "Rein in Russell" campaign of 2009 was union recognition and collective bargaining. Union leaders spoke at USAS meetings and lobbied university administrators to revoke licencing agreements with Russell Athletic, and students picketed and boycotted. Understanding FOTL's strong political standing as an employer in Honduras, the labour union sought direct negotiations only with corporate leaders. When FOTL was ready to respond, its executives negotiated an agreement with union leaders.

2. The labour rights as human rights approach. Labour Behind the Label (LBTL), an affiliate of the Clean Clothes Campaign, notes prominently on its web page, "A Living Wage is a Human Right" and "Worker Safety is a Human Right", and directly references the UDHR, Article 23 (LBTL, Undated). The LBTL listing of human rights abuses in the garment industry includes long hours, forced overtime, unsafe working conditions, and sexual, physical and verbal abuse. LBTL consumer activists liaise with governments and brands to remedy workers' rights violations and promote solidarity between workers and consumers. The campaign is largely conducted by activists on behalf of workers, but the LBTL activists fully acknowledge that labour union repression contributes to abuses and are pleased to work with trade unions to amplify garment workers' demands.

Despite an apparent symbiosis between human and labour rights, these two rightsholder approaches illuminate conceptual and pragmatic contrasts. The traditional labour rights approach views labour rights largely as aspirational rights that are won through collective action, whereas

${ }^{3}$ Fair Wear Foundation is an independent, non-profit organisation headquartered in Amsterdam, the Netherlands, that works to improve conditions for workers in garment factories.

${ }^{4}$ The Clean Clothes Campaign is a garment industry alliance of labour unions and non-governmental organisations founded in the Netherlands to identify and remedy workers' rights violations.

${ }^{5}$ USAS was conceived in 1997 by student activists working with the Union of Needletrades, Industrial and Textile Employees (UNITE!), a successor to the International Ladies Garment Workers Union. 
the human rights approach frames labour rights as basic rights that morally obligate the state and other actors who might impede or facilitate them. Importantly, the issue is not whether labour rights are human rights, although at some level of abstraction all rights are derivative of human rights, but when labour rights should be explicitly pursued as such. This issue has important implications both for the priority afforded labour rights and concerns regarding overuse of human rights framing.

\section{Two Approaches to Protecting Labour Rights}

The traditional labour approach operates on an ethic of utility, given that union leadership is elected to represent the interests of its members collectively, while the labour rights as human rights approach draws upon an ethic of rights which emphasises individual entitlements that cannot be overridden by utility. There has been a continued debate between labour advocates who use human rights as a language for advancing labour rights, and the traditional labour rights proponents who prize solidarity as a means for achieving freedom in the workplace and beyond (see, for example, McCartin, 2005 vs Friedman, 2005; Compa, 2008 vs Youngdal, 2009; McIntyre, 2008; Gross, 2009). For our purposes, it is only necessary to provide a brief overview of each approach.

\section{The labour rights as human rights approach}

Labour rights support lags behind human rights support for a number of reasons. First, human and labour rights appear to be associated with different values. Eighty per cent of Americans support the concept of human rights, particularly as it resonates with values of dignity and fairness (Jenkins and Hsu, 2008). It appears that human rights are viewed through a deontic lens that connotes ethical stature but directs less attention to socio-economic concerns and domestic labour law. Gross and Compa (2009: 8) assert that "workers are empowered when they are convinced - and convince the public - that they are vindicating their fundamental human rights, not just seeking a wage increase or more job benefits". Conversely, labour unions, the foremost purveyors of labour rights in the United States, prompt mixed views and some suspicion with respect to self-interest. In Gallup's 2020 poll, 65 per cent of respondents "approve" of labour unions and 70 per cent believe that they "mostly help their members", but at the same time 54 per cent of Americans believe that labour unions "hurt non-union workers" and 52 per cent believe that they hurt "the U.S. economy". While labour disputes can look self-interested and disruptive (Jarley and Kuruvilla, 1994), human rights framing offers the vocabulary to champion human flourishing and to shame those who oppose it, which is among its most effective aspects.

Second, the capacity and effectiveness of the labour movement in the United States is subject to challenge. In the US, private sector union membership has fallen to a seventy-year low of 6.5 per cent and faces intense corporate resistance (Bronfenbrenner, 2008; Bureau of Labor Statistics, 2016). The National Labour Relations Board (NLRB) records indicate that US employers violate labour law in over 40 per cent of union organising attempts (McNicholas et al., 2019). Labour unions' primary mandate is to represent their members' economic interests, and this objective has drawn them into broader social issues. Campaigns that are not specifically labour campaigns, such as the civil rights movement, have also benefitted from labour union support, while some observers see unions as threats to social harmony and economic stability (Kang, 2012). For labour advocates dispirited by setbacks to the labour movement, the human 
rights regime provides a potentially promising means of reversing labour's decline.

Third, reformulating labour rights as human rights that must be respected under international law can begin a process of change (Compa, 2003: 52), particularly in the international context of engaged and well-informed institutional stakeholders and human rights observers. Human rights appeals are appropriate when governments fail to protect their citizens' rights or infringe upon them. Reinecke and Ansari (2016) show how responsibility can be attributed to a target by framing an issue and its root cause in ways that support such an attribution. In terms of the basic human right of physical integrity alone, there are approximately 2.78 million deaths per year from work-related accidents or diseases, and 374 million non-fatal work-related injuries each year (ILO, 2019b). Hence, business and human rights (BHR) scholarship increasingly draws attention to corporate complicity in labour and human rights violations and their capacity to reduce or eliminate particular rights violations (Whelan, Moon and Orlitzky, 2009; Santoro, 2010), and corporations are increasingly adopting human rights language when deliberating their responsibilities (Wettstein, 2012a). These are clear benefits of human rights framing that the labour movement could refine and deploy with greater sophistication and purpose.

Finally, human rights discourse maintains an elevated public status because of its emotive and agenda-setting properties (Powers, 2014), and it seems apparent that human rights framing garners broader attention and casts the labour rights agenda in a different light. For example, Human Rights Watch is widely viewed as a highly credible observer of human rights matters; the Business and Human Rights Resource Centre monitors over 10000 companies to identify and redress abuses. These organisations endeavour to fairly represent both companies and their stakeholders on human rights issues that frequently entail labour violations, and report on both favourable and unfavourable practices. For example, Human Rights Watch has published investigations of the US meatpacking industry as well as labour abuses by transnational corporations in the United States and in the global apparel industry (Human Rights Watch, 2004, 2010, 2019). The news media often report on the investigations completed by these organisations, furthering their reach, and they have a very large number of social media and online followers (Human Rights Watch, 2020).

\section{The traditional labour rights approach}

Traditional labour rights proponents, particularly in the United States, argue that the ethos of "bread and butter" unionism ${ }^{6}$ that has historically characterised the US labour movement is more closely aligned with collective action and workplace democracy than to broad notions of fundamental human rights (Archer, 2010; Hattam, 2014). Although persons can pursue their human rights collectively, the human rights literature emphasises that human rights primarily refer to individuals in their relations with nation-states (e.g. Ignatieff, 2003). Accordingly, each individual worker, including those who oppose labour unions, has the right to pursue employment without being compelled to join a labour union; arguments in opposition to unions, such as "right to work" and "pay-check protection" laws, are often couched in terms of individual rights (Savage, 2008). Proponents of the traditional labour rights approach argue that highlighting the rights language mires the debate in the individualistic ideological terrain where opponents to labour unions are most comfortable, and does not strengthen union protections

\footnotetext{
${ }^{6}$ An approach to unionism that tended to disregard social issues in favour of economic issues. It was popularized by Samuel Gompers, first President of the American Federation of Labor (AFL).
} 
because it speaks to the limitation of state power rather than its augmentation (e.g. Lichtenstein, 2002; McCartin, 2005).

It can also be difficult for the individual worker to access the human rights regime for repeated labour rights violations. The US Department of Labour indicates that there was nearly one billion dollars in illegally unpaid wages between 2010 and 2014 (Greenhouse, 2014a), but wage and hour violations are not reasonably pursued as individual human rights abuses. According to Maina Kiai, the UN Special Rapporteur on freedom of association, the ability to exercise rights in the workplace enables workers to enjoy a broad range of economic, social, cultural and political rights (UNSR, 2016). Hence, the labour rights approach elevates the dignity of the individual, but it does so through collective action (Leader, 1992).

Voluntary approaches, such as the United Nations General Principles, provide standards that can apply to all employers, but their effectiveness is subject to debate (Short, 2013; Ramachandra, 2016). Traditional labour rights proponents can point to research indicating that corporations manipulate performance reports with false claims (Callery and Perkins, 2020), and maintain that voluntary approaches are often ineffective, particularly with respect to workers' union rights (Vogel, 2010; Locke, Rissing and Pal, 2013; Egels-Zandén and Merk, 2014). Hence, wages and working conditions should not be determined solely as matters of corporate prerogative, benevolent or otherwise, but also through worker agency. Bair and Palpacuer (2015) argue that the labour rights as human rights approach weakens worker agency by drawing attention away from the labour issues that animate the typical worker, and toward the state and to legal remedies.

Adherents to the traditional labour rights approach argue that the "heartland of labour rights" consists of procedural rights (Kolben, 2010), because they enable workers to maintain a democratic voice in the workplace. The Executive Director of Human Rights Watch concurs, candidly acknowledging that the strength of the human rights regime is in their shaming methodology - their ability to expose wrongdoing to public opprobrium - but their rhetoric is not effective in the socio-economic realm where distributive justice is the goal (Roth, 2004). Labour unions have, however, been relatively effective in securing a share of economic rents for their members (Hirsch, 2004; Madland, Walter and Bunker, 2011). Supporters of traditional labour rights emphasise joint governance processes and thus they are more likely to maintain effective monitoring and provide a consistent challenge to workplace practices that place workers at risk (Morantz, 2013; Zoorob, 2018; Sojourner and Yang, 2020). Conversely, Compa (2005) maintains that the concept of industrial democracy is too diffuse to sustain organising, bargaining and labour law reform campaigns. The tide of neo-liberalism appears to have moved political economy away from social solidarity, and employers and courts have agreed that collective bargaining practices pose an undue burden on the free flow of commerce. Without grounding in basic rights, labour union organising and bargaining are subject to the caprice of free markets. Moreover, human rights framing can help build alliances that the labour movement needs, and it is necessary to pursue all avenues of labour union revitalisation.

\section{The Need for a Hybrid Approach}

To some degree the labour rights as human rights and traditional labour rights approaches talk past one another. McIntyre (2008) argues that even the meanings of the two terms are in doubt in the United States. He contends that US labour rights are defined quite narrowly, and the nature of human rights shifts in accordance with US foreign policy; consequently, he questions whether 
defining labour rights as human rights even matters. Clearly there are many occasions when human and labour rights violations occur simultaneously, such as when labour leaders are killed or disappear, or workers are trafficked or subjected to inhumane conditions. The potent human rights language is a useful means of advancing labour rights, but abandoning labour rights too hastily can give the impression that labour rights and the labour movement are, in themselves, somehow deficient. Hence, labour advocates would benefit from an organising principle that simultaneously defends the act of organising itself (that is, labour rights as human rights) and that duly recognises and respects the role of labour unions in protecting the rights of workers once they are established (that is, traditional labour rights). Human and labour rights can be mutually reinforcing, and this is most likely if there are means to discipline the relationship between the two approaches. The principle of subsidiarity offers both a conceptual and a pragmatic framework for thinking about such interdependence and employing the relative strengths of each.

\section{The Principle of Subsidiarity}

As defined earlier in this article, subsidiarity is a regulative principle that disciplines the way various persons and institutions interact with one another in pursuit of their common objectives. The principle is generally employed to address the undue intervention of any one sphere in another, such as state interventions into other spheres of life (Whitmore, 2004), but it also has relevance for how large and remote institutions coordinate with satellite operations. For example, in discussing the implications of unrestrained capitalism and totalitarianism, Pope Pius XI provides a rendering of the principle of subsidiarity:

[A] community of a higher order should not interfere in the internal life of a community of a lower order, depriving the latter of its functions, but rather should support it in case of need and help to co-ordinate its activity with the activities of the rest of society, always with a view to the common good (Catholic Church, 2000: para. 1883). ${ }^{7}$

Subsidiarity was later included in the Maastricht Treaty and remains a legally binding principle of the European Community. It has been used by Member State Parliaments to strike down proposed European Union (EU) labour rules on the basis that their subject matter was better addressed by national authorities (European Parliament, 2021). ${ }^{8}$ Quite simply, this principle indicates that the institution most proximate to an issue is typically best suited to address its intricacies and nuances.

However, subsidiarity is necessarily viewed within the purview of an accompanying solidarity. Paradoxically, subsidiarity can either proscribe or prescribe action and, in varied circumstances, either limit or require the mantle of human rights. With respect to labour rights specifically, solidarity is present when workers align their own struggles with the struggles of their peers. Not only does subsidiarity require that actions are taken at the lowest level possible but also at the highest level necessary to address a problem (Clark, 2014). Accordingly, extreme situations require support from remote actors such that they are not divorced from responsibility and accountability. For example, labour leaders are still subject to violence (ILO, 2012; Greenhouse, 2014b). Under the principle of subsidiarity, if there are no local or national labour rights

\footnotetext{
7 http://www.scborromeo.org/ccc/p3s1c2a1.htm\#1883

8 The authors would like to thank an anonymous reviewer for bringing this point to their attention.
} 
structures in place for their protection, these workers could appropriately draw support from the international human rights regime. Indeed, Carozza (2003: 40) states that "subsidiarity fits international human rights law so well that the basic values of the principle can reasonably be regarded as already implicitly present in the structure of international human rights law".

\section{Aligning the Human and Labour Rights Orders}

The International Labour Organization (ILO) is uniquely suited to connect the human and labour rights regimes because, as a United Nations (UN) agency, it specifies human rights principles directly in the labour rights context. For example, child labour abuses are addressed in the Convention on the Rights of the Child but also in ILO convention 182 concerning the worst forms of child labour; workplace discrimination is tackled by the UN Conventions on the Elimination of Racial Discrimination and the Elimination of Discrimination Against Women but specified to employment in several ILO conventions (i.e., 100, 111, 156, 183). Ideally the ILO's expertise regarding rights and implementation supports the labour rights regime in operationalising human rights for workers while also bringing the normative bearing of a UN agency.

\section{The role of core labour standards}

To date, the ILO has established over seventy-five active conventions (ILO, 2019c). However, the Declaration on Fundamental Principles and Rights at Work designates only four categories of fundamental principles and rights at work, often referred to as core labour standards essential for decent work: freedom of association, elimination of forced labour, abolition of the worst forms of child labour, and elimination of discrimination (ILO, 1998, 2019a). The freedom of association (FOA) core labour standard includes the right to form a labour union and the right to bargain collectively (Conventions 87 and 98, respectively). These core labour standards constitute customary rules by which all ILO members are bound by virtue of their membership to respect, promote and realise in good faith, even if they have not been ratified in their respective countries. Note the language regarding core labour standards and how it harkens to human rights in binding countries and overriding their sovereignty (Beitz, 2009).

There are both normative and pragmatic reasons to promulgate the core labour standards as human rights. Normatively, recognising the expertise of workers in matters that affect them and supporting their agency affirms their dignity and capacity. Also, the core labour standards are basic, indispensable rights that are not achieved through any other provision. Mantouvalou (2012) has argued that because labour rights entail criteria that are compelling, stringent, universal and timeless, they are as valid as other widely acknowledged human rights, such as security of person. The core labour standards warrant human rights standing because they address: (a) issues that require the same rules in each state to ensure workers' well-being; (b) practices that have significant cross-border implications or spill-over effects, such that national policies are reinforced by international policies; and (c) issues where the costs of a policy failure are catastrophic (for example, killing labour leaders). Fittingly, Human Rights Watch describes freedom of association as a vital component of societies where human rights are respected (Compa, 2000), and the United Nations Global Compact asserts that core labour standards should be respected by all businesses. 


\section{Subsidiarity in practice}

Subsidiarity provides an analytically descriptive way to align the existing structures of human rights advocacy with traditional labour rights issues while also justifying the necessity of cooperation and clear roles. It is useful to divide labour rights into core labour standards (that is, basic labour rights) that are duly addressed as human rights, and ancillary labour rights (that is, aspirational rights) that are secured as a product of basic rights. Ancillary labour rights address the day-to-day work conditions that both emanate from and complement the core labour standards. For example, two of the four pillars of the ILO's Decent Work Agenda (ILO, Undated) - employment creation and rights at work - are aspirational rights that can be secured through the core labour standards. Collective bargaining has a substantial impact on ancillary rights regarding workplace democracy, work-life balance and wage rates (Farber et al., 2018). Regarding this point, the workers' delegate for Costa Rica argued to an ILO conference that it is pointless to speak of the decent work agenda without mentioning freedom of association (ILO, 2010).

As shown in Figure 1, under the disciplining principle of subsidiarity the core labour standards are protected directly through the central human rights [A], and all other labour rights are protected primarily through the sub-unit labour rights regime (freedom of association and collective bargaining), and secondarily as human rights when core labour standards are inaccessible or unenforced [B]. The human rights regime helps safeguard labour unions and collective bargaining through the core labour standards, but after achieving that objective it simply supports the labour rights regime in the workplace. In this division of labour both human and labour rights are preferred but at different levels. Hence, subsidiarity enables the human rights regime to support core labour rights where they exist and to replace them where they are absent.

Hence, labour rights will be pursued as human rights, in accordance with the principle of subsidiarity, only insofar as they cannot be sufficiently realised through labour rights mechanisms, but can by reason of the scale, conditions or effects be better realised when presented as human rights. Because subsidiarity is not rigid or precise and is challenging to implement (Carozza, 2003), we offer three criteria to guide its application: necessity, scope and efficiency (e.g. Føllesdal, 1998).

First, where there is not a compelling case of necessity, it is presumed that an employment issue is left to labour rights mechanisms. That is, the labour rights sub-unit enjoys deference and the burden of argument is left to those who would pursue a labour issue as a human rights issue. Second, the scope of human rights intervention in matters of labour rights should be construed conservatively with the intent of limiting it to instances where labour rights mechanisms, such as core labour standards, have been exhausted. When discrepancies between the human rights and labour rights approaches emerge, it is necessary to respect the autonomy of localised labour rights remedies and practices, unless they are normatively lacking. Indeed, labour unions are subject to the same normative shortcomings (such as corruption or discrimination) as other organisations. Third, the criterion of comparative efficiency requires that the central unit (human rights) must clearly secure the desired outcomes better than the sub-unit (labour rights) due to differential ability or effectiveness. For instance, as will be demonstrated below, appeals to international human rights soft law might indeed be more effective than labour rights mechanisms in addressing transnational corporations operating in under-regulated countries. In sum, for labour advocates of all stripes, a subsidiarity-based human and labour rights strategy might generally entail shaming the state and striking the employer. When core labour standards are abridged, then 
the shaming methodologies of human rights should be directed toward the state, drawing on international soft law. In other cases, when core labour standards are respected, the labour rights methodology of negotiation and work actions such as strikes and slowdowns can be employed in order to maintain focus on the private sector.

\section{Human Rights Regime}

Primary support to core labour standards Secondary support to labour rights regime

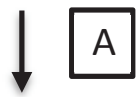

Core Labour Standards Focus - freedom of association

Primary support from human rights regime and to labour rights regime

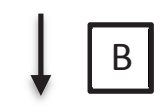

\section{Labour Rights Regime Focus - wages and working conditions}

Primary support from core labour standards Secondary support from human rights regime

Figure 1: Core labour standards and subsidiarity 
As shown in Figure 1, the principle of subsidiarity does not dismiss the notion of labour rights as human rights, but reasonably specifies its role relative to the traditional labour rights approach. There have been instances of FOA restrictions in the United States, where unions have aptly turned to the human rights regime for support. For example, the Teamsters waged a human rights campaign against Maersk, the Denmark-based international shipping company. Maersk fired drivers, whom they deemed independent contractors, for collective activity, and successfully argued that, as contractors are not employees, they can be dismissed with impunity. The Teamsters' human rights campaign was consistent with the subsidiarity of labour rights to human rights because the workers were terminated for exercising freedom of association and the US government failed to protect their core labour rights (Mongelluzzo, 2006). ${ }^{9}$ Likewise, Human Rights Watch has filed reports on the US meatpacking and poultry industries, alleging that companies violated workers' human rights by firing union organisers and labour rights by subjecting workers to deplorable work conditions (Greenhouse, 2005; Human Rights Watch, 2004). The distinction between human rights and labour rights aptly respects the role and importance of each.

As a matter of practice, subsidiarity also implies that most labour disagreements will not be addressed by the human rights approach. For example, when employment discrimination occurs in Canada, a worker can file a human rights complaint with the regional human rights tribunal or file a grievance through her labour union. The grievance arbitration process must examine any human rights issues that are entailed in a grievance, and this makes an immediate human rights complaint redundant. If a worker engages both regimes, the human rights tribunal typically defers the human rights complaint until the arbitrator has rendered a decision (British Columbia Human Rights Tribunal, 2016). In the United States as well, private grievance mechanisms, which are a centrepiece of the traditional labour relations approach, are more readily accessible and responsive than the human rights regime.

\section{The continuing role of the human rights regime}

The human rights regime has traditionally addressed countries that fail to enforce core labour standards and freedom of association, and this is as it should be. In 2002, the US Supreme Court ruled in Hoffman Plastics v. NLRB that undocumented workers who are fired for union organising are not entitled to back pay for lost wages. Human Rights Watch (2004) filed a complaint and two human rights bodies, the Inter-American Court of Human Rights and the ILO's Committee on Freedom of Association, ruled that the Supreme Court decision violated international obligations to protect workers' right to organise. ${ }^{10}$ The European Court of Human Rights has also held that the absence of legislation supporting the core labour standards constitutes a breach of the European Convention on Human Rights (Ewing and Hendy, 2012). The disconnect in jurisprudence between these international bodies is an ongoing challenge, and there is no mechanism to enforce international soft law decisions, but the rulings increase normative pressure for compliance.

Also, in some cases there is an ongoing need for the human rights regime to directly protect labour rights. First, labour unions themselves, either by policy or benign neglect, can neglect parttime workers, non-permanent workers and stateless workers such as refugees and asylum seekers. There are over 164 million migrant workers in the global workforce (ILO, 2018). In the United

\footnotetext{
${ }^{9}$ Maersk subsequently stopped its reprisals against union workers.

${ }^{10}$ US labour law regarding undocumented workers was not changed as a consequence of these rulings.
} 
States, approximately one million farmworkers experience abuses including fraud, coercion, retaliation and forced labour (US Department of Labour, 2016; International Labor Recruitment Working Group, 2017). Second, many workers lack domestic protections and thus work violations would be pursued directly as human rights abuses. There are also heinous violations to human dignity for which immediate human rights action is required. One example is the use of school-aged children to mine mica in Madagascar (Cavazuti et al., 2019).

The human rights vs labour rights debate is useful. Traditional labour advocates have long recognised the need to expand the tactical playbook to better encompass the interests of diverse workers and new constituencies (Frege and Kelly, 2004; Voss, 2010). The Teamsters campaign against Maersk, and the Human Rights Watch report that distinguishes human rights (firing union organisers) from labour rights (deplorable work conditions) are promising. It is also reasonable that, to the extent that human rights NGOs are involved in labour issues, they will bring their discourse to the process. It falls to labour advocates of both stripes to align the varying modes of activism in terms of tactics rather than turf.

\section{Conclusion}

In advocating a more disciplined embrace of labour rights as human rights, this article makes three primary contributions. First, it reserves a space for labour rights in the more popular human rights discourse. Second, it advances a framework for coordinating the human and labour rights regimes that addresses those who suggest simply using both human and labour rights. Third, it spotlights core labour standards as the key linking mechanism between human and labour rights, a mechanism which has been underutilised by both human and labour rights advocates. While labour rights are part of the broad human rights consensus, they must still be defended on their own merits. Likewise, human rights advocacy is indispensable in making the case that some terms and conditions of employment should not be determined solely by labour market competition or by workers' individual or collective bargaining power, but extended to all workers (Frege and Kelly, 2013). Hence, reasserting the core labour rights of the ILO - freedom of association and right to bargain collectively, freedom from discrimination, freedom from forced labour, freedom from child labour - as basic human rights begins a different conversation with employers. Developing and applying subsidiarity as a principle with which to align human and labour rights is challenging, but by forcing labour leaders, advocates and activists to consider fully the level at which labour rights are best accomplished, it can potentially help both movements to pursue their common goals more effectively.

\section{References}

Alston, P. (2005) Labour Rights as Human Rights: The Not So Happy State of the Art. In Labour Rights as Human Rights, edited by P. Alston. Oxford, UK: Oxford University Press.

Archer, R. (2010) Why is There no Labor Party in the United States? Princeton, NJ: Princeton University Press.

Arnold, D.G. (2010) Transnational Corporations and the Duty to Respect Basic Human Rights. Business Ethics Quarterly: 3: 371-399.

Atleson, J. (2004) The Voyage of the Neptune Jade: The Perils and Promises of Transnational Labor Solidarity. Buff. L. Rev., 52: 85-183. 
Bair, J. and F. Palpacuer (2015) CSR Beyond the Corporation: Contested Governance in Global Value Chains. Global Networks, 15(s1): S1-S19.

Beitz, C.R. (2009) The Idea of Human Rights. New York: Oxford University Press.

Benford, R.D. and D.A. Snow (2000) Framing Processes and Social Movements: An Overview and Assessment. Annual Review of Sociology, 26: 611-639.

British Columbia Human Rights Tribunal (2016) Rule of Practice and Procedure - Effective January 15, 2016 (Amended November 27, 2018). Vancouver: British Columbia Human Rights Tribunal.

Brody, D. (2001) Labour Rights as Human Rights: A Reality Check. British Journal of Industrial Relations, 39(4): 601-605.

Bronfenbrenner, K. (2008) The Experience of Organizing in the Context of the Global Economy. In The State of the Unions: Challenges Facing Organised Labour in Ireland, edited by T. Hastings. Dublin, Ireland: Liffey Press.

Bureau of Labor Statistics (2016) Union Membership Summary. Washington, DC: Bureau of Labor Statistics.

Callery, P.J. and J. Perkins (2020) Detecting False Accounts in Intermediated Voluntary Disclosure. Academy of Management Discoveries, 13 January 2020. https://doi.org/10.5465/amd.2018.0229.

Carozza, P.G. (2003) Subsidiarity as a Structural Principle of International Human Rights Law. American Journal of International Law, 97: 38-79.

Catholic Church (2000) Catechism of the Catholic Church. Second edition. London: Continuum International.

Cavazuti, L., C. Romo, C. McFadden and R. Shapiro (2019) "Zone Rogue": An Army of Children Toils in African Mines. NBC News. https://www.nbcnews.com/news/all/army-children-toil-african-micamines-n1082916 (accessed 30 September 2021).

Chozick, A. (2015) Hillary Clinton' Beijing Speech on Women Resonates 20 Years Later. The New York Times, 6 September 2015.

Clark, M.J. (2014) The Vision of Catholic Social Thought: The Virtue of Solidarity and the Praxis of Human Rights. Minneapolis, MN: Fortress Press.

Clinton, H.R. (1996) Women's Rights are Human Rights. Women's Studies Quarterly, 24(1): 98-101.

Compa, L.A. (2000) Unfair Advantage: Workers' Freedom of Association in the United States under International Human Rights Standards. New York: Human Rights Watch.

Compa, L.A. (2003) Workers' Freedom of Association in the United States: The Gap between Ideals and Practice. ILR School digital collection, https://hdl.handle.net/1813/75243 (accessed 28 January 2022).

Compa, L.A. (2005) Responses. Dissent, 52(1): 66-68.

Compa, L.A. (2008) Labor's New Opening to International Human Rights Standards. Working USA: The Journal of Labor and Society, 11(1): 99-123.

Dawkins, C.E. (2012) Labored Relations: Corporate Citizenship, Labor Unions, and Freedom of Association. Business Ethics Quarterly, 22(3): 473-501.

Egels-Zandén, N. and J. Merk (2014) Private Regulation and Trade Union Rights: Why Codes of Conduct have Limited Impact on Trade Union Rights. Journal of Business Ethics, 123(3): 461-473.

Estlund, C.L. (2002) The Ossification of American Labor Law. Columbia Law Review, 102: 1532-1544.

European Parliament (2021) The Principle of Subsidiarity. http://www.europarl.europa.eu/factsheets/en Lsheet/7/the-principle-of-subsidiarity (accessed 20 January 2022).

Ewing, K.D. and J. Hendy (2012) Unfair Dismissal Law Changes - Unfair? Industrial Law Journal, 41(1): $115-121$. 
Farber, H.S., D. Herbst, I. Kuziemko and S. Naidu (2018) Unions and Inequality over the Twentieth Century: New Evidence from Survey Data. NBER Working Paper No. 24587. Cambridge, MS: National Bureau of Economic Research.

Fenwick, C. and T. Novitz (2010) Conclusion: Regulating to Protect Workers' Human Rights. In Human Rights at Work: Perspectives on Law and Regulation, edited by C. Fenwick and T. Novitz. Oxford, UK: Hart Publishing.

Fletcher, B. and F. Gapasin (2008) Solidarity Divided: The Crisis in Organized Labor and a New Path toward Social Justice. Berkeley, CA: University of California Press.

Føllesdal, A. (1998) Survey Article: Subsidiarity. Journal of Political Philosophy, 6(2): 190-218.

Frege, C.M. and J. Kelly (2004) Union Strategies in Comparative Context. In Varieties of Unionism: Strategies for Union Revitalization in a Globalizing Economy, edited by C.M. Frege and J. Kelly. Oxford, UK: Oxford University Press.

Frege, C.M. and J. Kelly (2013) Comparative Employment Relations in the Global Economy: London: Routledge.

Friedman, S. (2005) Democratizing the Demand for Workers' Rights: Toward a Re-framing of Labor's Argument. Dissent, 52(1): 68-69.

Fudge, J. (2007a) The New Discourse of Labor Rights: From Social to Fundamental Rights. Comparative Labor Law and Policy Journal, 29: 29-66.

Fudge, J. (2007b) The New Discourse of Labor Rights: From Social to Fundamental Rights. Comparative Labor Law and Policy Journal, 29: 29-43.

Gallup (2020) Labour Unions. https://news.gallup.com/poll/12751/labor-unions.aspx (accessed 20 January 2022).

Greenhouse, S. (2005) Meat Packing Industry Criticized on Human Rights Grounds. The New York Times, January 25.

Greenhouse, S. (2014a) More Workers are Claiming Wage Theft. The New York Times, August 31.

Greenhouse, S. (2014b) Union Leaders Attacked at Bangladesh Garment Factories, Investigations Show. The New York Times, December 22.

Gross, J.A. (2002) Worker Rights as Human Rights: Wagner Act Values and Moral Choices. University of Pennsylvania Journal of Labor and Employment Law, 4(3): 479-492.

Gross, J.A. (2009) Takin' it to the Man: Human Rights at the American Workplace. In Human Rights in Labor and Employment Relations: International and Domestic Perspectives, edited by J.A. Gross and L.A. Compa. Champaign, IL: Labor Employment Relations Association.

Gross, J.A. and L.A. Compa (2009) Introduction. In Human Rights in Labor and Employment Relations: International and Domestic Perspectives, edited by J.A. Gross and L.A. Compa. Champaign, IL: Labor and Employment Relations Association, University of Illinois.

Hattam, V.C. (2014) Labor Visions and State Power: The Origins of Business Unionism in the United States. Princeton, NJ: Princeton University Press.

Hilgert, J. (2009) A New Frontier for Industrial Relations: Workplace Health and Safety as a Human Right. In Human Rights in Labor and Employment Relations: International and Domestic Perspectives, edited by J.A. Gross and L.A. Compa. Chamaign, IL: Labor and Employment Relations Association, University of Illinois.

Hirsch, B.T. (2004) What Do Unions Do for Economic Performance? Journal of Labor Research, 25(3): 415455.

Human Rights Watch (2004) Blood, Sweat, and Fear: Workers' Rights in U.S. Meat and Poultry Plants. New York: Human Rights Watch.

Human Rights Watch (2010) A Strange Case, September 2. New York: Human Rights Watch. 
Human Rights Watch (2019) Paying for a Bus Ticket and Expecting to Fly: How Apparel Brand Purchasing Practices Drive Labor Abuses. New York: Human Rights Watch.

Human Rights Watch (2020) About Us. https://www.hrw.org/about/about-us (accessed 30 September 2021).

Ignatieff, M. (2003) Human Rights as Politics and Idolatry. Princeton, NJ: Princeton University Press.

International Labour Organization (ILO) (Undated) The Decent Work Agenda. https://www.ilo.org/asia Ldecentwork/lang--en/index.htm (accessed 20 January 2022).

International Labour Organization (ILO) (1998) ILO Declaration on Fundamental Principles and Rights at Work and its Follow-up. Geneva: ILO.

International Labour Organization (ILO) (2010) Report of the 17th American Regional Meeting. Santiago de Chile. Geneva: ILO.

International Labour Organization (ILO) (2012) Observation (CEACR) - Adopted 2011, 101st ILC session (2012) Freedom of Association and Protection of the Right to Organise Convention, 1948 (No. 87). Geneva: ILO.

International Labour Organization (ILO) (2018) ILO Global Estimates on International Migrant Workers Results and Methodology. Geneva: ILO.

International Labour Organization (ILO) (2019a) Rules of the Game: An Introduction to the Standards-Related Work of the International Labour Organization. Geneva: ILO.

International Labour Organization (ILO) (2019b) Safety and Health at Work. Geneva. Geneva: ILO.

International Labour Organization (ILO) (2019c) Up-to-Date Conventions and Recommendations. https://www.ilo.org/dyn/normlex/en/f?p=NORMLEXPUB:12020:0::NO::: (accessed 20 January 2022).

International Labor Recruitment Working Group (2017) The American Dream Up for Sale: A Blueprint for Ending International Labor Recruitment Abuse. Geneva: ILRWG.

Jarley, P. and S. Kuruvilla (1994) American Trade Unions and Public Approval: Can Unions Please All of the People All of the Time? Journal of Labor Research, 15(2): 97-116.

Jenkins, A. and K.S. Hsu (2008) American Ideals and Human Rights: Findings from New Public Opinion Research by the Opportunity Agenda. Fordham Law Review, 77: 439-461.

Kang, S.L. (2012) Human Rights and Labor Solidarity: Trade Unions in the Global Economy. Philadelphia, PA: University of Philadelphia Press.

Kolben, K. (2010) Labor Rights as Human Rights. Virginia Journal of International Law, 50: 449-480.

Labour Behind the Label (LBTL) (Undated) A Living Wage is a Human Right. https:/ / labourbehindthelabel.org/campaigns/living-wage (accessed 11 January 2022).

Leader, S. (1992) Freedom of Association: A Study in Labor Law and Political Theory: New Haven, CT, and London: Yale University Press.

Lichtenstein, N. (2002) State of the Union: A Century of American Labor. Princeton, NJ: Princeton University Press.

Lichtenstein, N. (2003) The Rights Revolution. The New Labor Forum, 12: 60-73.

Locke, R.M., B.A. Rissing and T. Pal (2013) Complements or Substitutes? Private Codes, State Regulation and the Enforcement of Labour Standards in Global Supply Chains. British Journal of Industrial Relations, 51(3): 519-552.

Madland, D., K. Walter and N. Bunker (2011) Unions Make the Middle Class. Washington, DC: Center for American Progress.

Mantouvalou, V. (2012) Are Labour Rights Human Rights? European Labour Law Journal, 3(2): 151-172. 
Marino, K.M. (2019) Feminism for the Americas: The Making of an International Human Rights Movement. Charlotte, NC: UNC Press Books.

Matten, D. and A. Crane (2005) Corporate Citizenship: Toward an Extended Theoretical Conceptualization. Academy of Management Review, 30(1): 166-179.

McCartin, J.A. (2005) Democratizing the Demand for Workers' Rights: Toward a Re-framing of Labor's Argument. Dissent, 52(1): 61-71.

McIntyre, R.P. (2008) Are Worker Rights Human Rights? Ann Arbor, MI: University of Michigan Press.

McNicholas, C., M. Poydock, J. Wolfe, B. Zipperer, G. Lafer and L. Loustaunau (2019) Unlanful: U.S. Employers are Charged with Violating Federal Law in 41.5\% of all Union Election Campaigns. Washington, DC: Economic Policy Institute.

Mongelluzzo, B. (2006) Teamsters want Maersk to Abide by UN Workers Rules. Journal of Commerce Online. April 11.

Morantz, A.D. (2013) Coal Mine Safety: Do Unions Make a Difference? ILR Review, 66(1): 88-116.

Moyn, S. (2018) Not Enough: Human Rights in an Unequal World. Cambridge, MS: Harvard University Press.

Nickel, J. (1987) Making Sense of Human Rights: Philosophical Reflections on the Universal Declaration of Human Rights. Berkeley, CA: University of California Press.

Nussbaum, M. (2002) Capabilities and Human Rights. In Global Justice and Transnation Politics: Essays on the Moral and Political Challenges of Globalization, edited by P. de Greiff and C.P. Cronin. Cambridge, MA: MIT Press.

Powers, M. (2014) The Structural Organization of NGO Publicity Work: Explaining Divergent Publicity Strategies at Humanitarian and Human Rights Organizations. International Journal of Communication, 8: 90-107.

Ramachandra, K. (2016) US Plan on Responsible Business Conduct is Too Little, Too Late. New York: Human Rights Watch.

Reinecke, J. and S. Ansari (2016) Taming Wicked Problems: The Role of Framing in the Construction of Corporate Social Responsibility. Journal of Management Studies, 53(3): 299-329.

Roth, K. (2004) Defending Economic, Social and Cultural Rights: Practical Issues faced by an International Human Rights Organization. Human Rights Quarterly, 26: 63-73.

Santoro, M.A. (2010) Post-Westphalia and its Discontents: Business, Globalization, and Human Rights in Political and Moral Perspective. Business Ethics Quarterly, 20(2): 285-297.

Savage, L. (2008) Labour Rights as Human Rights? A Response to Roy Adams. Just Labour: The Canadian Journal of Work and Society, 12: 68-75.

Short, K. (2013) 5 Reasons American Companies Refused to Sign Bangladesh Safety Accord. Huffington Post, July 11. http://www.huffingtonpost.com/2013/07/11/rival-bangladesh-factory-safety-plans_n 3574260.html (accessed 10 March 2016).

Sojourner, A. and J. Yang (2020) Effects of Union Certification on Workplace-safety Enforcement: Regression-discontinuity Evidence. ILR Review: 0019793920953089 (online only).

Tversky, A. and D. Kahneman (1990) Rational Choice and the Framing of Decisions. The Journal of Business, (59): 251-278.

Tyler, P. (1995) Hillary Clinton, in China, Details Abuse of Women. The New York Times. September 6.

United Nations Special Representative (UNSR) (2016) UN Special Rapporteur on the Rights to Freedom of Peaceful Assembly and Association to Present 2016 Report to the UN General Assembly. New York: United Nations.

United States Department of Labor (2016) The National Agricultural Workers Survey: Demographic and Employment Characteristics. Washington, DC: Department of Labor. 
Vogel, D. (2010) The Private Regulation of Global Corporate Conduct. Business \& Society, 49(1): 68-87.

Voss, K. (2010) Democratic Dilemmas: Union Democracy and Union Renewal. Transfer: European Review of Labour and Research, 16(3): 369-382.

Walchuk, B. (2011) Union Democracy and Labour Rights: A Cautionary Tale. Global Labour Journal, 2(2): $106-124$.

Wettstein, F. (2012a) CSR and the Debate on Business and Human Rights: Bridging the Great Divide. Business Ethics Quarterly, 22(4): 739-770.

Wettstein, F. (2012b) Silence as Complicity: Elements of a Corporate Duty to Speak Out Against the Violation of Human Rights. Business Ethics Quarterly, 22(1): 37-61.

Whelan, G., J. Moon and M. Orlitzky (2009) Human Rights, Transnational Corporations and Embedded Liberalism: What Chance Consensus? Journal of Business Ethics, 87: 367-383.

Whitmore, T.D. (2004) Catholic Social Teaching: Starting with the Common Good. In Living the Catholic Social Tradition:. edited by K.M. Weigert and K.K. Alexia. New York: Sheed and Ward.

Wood, S. (2012) The Case for Leverage-based Corporate Human Rights Responsibility. Business Ethics Quarterly, 22(1): 63-98.

Youngdahl, J. (2009) Solidarity First: Labor Rights are Not the Same as Human Rights. New Labor Forum (Murphy Institute), 18(1): 30-37.

Zoorob, M. (2018) Does "Right to Work Imperil the Right to Health? The Effect of Labor Unions on Workplace Fatalities. Occupational and Environmental Medicine, 75(10): 736-738.

\section{BIOGRAPHICAL NOTES}

CEDRIC DAWKINS is associate professor of management at the Quinlan School of Business, Loyola University Chicago. His research focuses on agonism and dissensus in stakeholder engagement, connections between labour rights and corporate social responsibility, and global labour activism. His work appears in journals such as Business and Society, the Journal of Business Ethics and Business Ethics Quarterly. He serves as associate editor of Business Ethics Quarterly. [Email: cdawkins@luc.edu]

Christina DAwkins holds an M.A. in Human Rights Studies from Columbia University. She is the founder and principle for A4Abolitionist, a social justice consultancy to advise artists and educators advancing justice for the most vulnerable populations, and the Abolition Project, a non-profit think-and-do tank for abolitionists. She has developed curricula and workshops for the Oxford Consortium for Human Rights, Harvard University and Brown University, among others. [Email: christina@a4abolitionist.org] 